\title{
Improvement of anaemia in haemodialysed patients after viral or toxic hepatic cytolysis
}

\author{
PIERRE SIMON, ALAIN MEYRIER, TUGDUAL TANQUEREL, KIM-SENG ANG
}

\section{Summary and conclusions}

Thirty patients receiving haemodialysis, including two who had undergone bilateral nephrectomy, showed significant increases $(p<0.001)$ in packed cell volume, haemoglobin concentration, and reticulocyte count during an episode of viral or toxic liver cytolysis. In 19 cases the episode lasted a mean of 5.0 \pm SD 2.9 months and was accompanied by improved haematological values for a mean of $12.0 \pm 6.0$ weeks. Of the remaining patients, in whom the episode lasted a mean of $8.0 \pm 3.5$ months $(p<0.02)$, seven showed continued improvement a mean of $30.0 \pm 16.0$ weeks after cytolysis. In eight patients in this group there was an apparent correlation between persistently increased haemoglobin concentrations and biopsy evidence of chronic hepatitis.

The findings suggest that the reduction in anaemia resulted from enhanced red-cell production mediated by secretion of erythropoietin from regenerating liver cells. If confirmed this might have important implications for the treatment of anaemia in chronic renal insufficiency.

\section{Introduction}

Anaemia in chronic renal failure is associated with a reduced life span of erythrocytes and diminished erythropoiesis. ${ }^{1}$ The impaired red-cell production probably has a multifactorial aetiology, including uraemic toxicity ${ }^{2}$ and reduced production of renal erythropoietin. ${ }^{3}$ The lack of renal erythropoietin may these patients to see whether injured or regenerating liver has a vicarious erythropoietic role in uraemia.

\section{Patients and methods}

We studied 30 patients ( 20 men and 10 women) retrospectively. They had been receiving haemodialysis for 12-78 months, and two had undergone bilateral nephrectomy two years and one year respectively after beginning haemodialysis. All suffered an episode of liver cytolysis (mean maximum serum alanine transaminase (serum ALT; SGPT) activity $311.5 \pm \mathrm{SD} 221.8 \mathrm{IU} / 1$ (normal $\leqslant 40.0 \mathrm{IU} / \mathrm{l})$ ), which had lasted for a mean of $6.0 \pm$ SD 3.4 months. Nineteen of the episodes had resulted from a viral hepatitis (caused by hepatitis B surface antigen ( $\mathrm{HBsAg}$ ) in 18 cases and cytomegalovirus (CMV) in one); nine from drug toxicity (allopurinol in four cases, fluoxymesterone in two, methyldopa in two, and aspirin and paracetamol in one); and two were unexplained. Of the nine episodes caused by drug toxicity, five occurred in carriers of HBsAg. In no case was liver cytolysis accompanied or followed by impaired liver function.

In each patient the predialysis packed cell volume, haemoglobin concentration, mean cell volume, reticulocyte count, and serum iron concentration were determined at least monthly before, during, and after the episode of cytolysis. Out of 11 patients with a protracted episode, eight underwent liver biopsy (Menghini) repeated after an interval of one year. All patients were taking folic acid supplements and received intravenous iron at regular intervals. The mode of dialysis continued unchanged during the observation period. Before the episode of cytolysis four patients, including the two anephric patients and one with chronic respiratory failure, required regular blood transfusions because of poor tolerance of haemoglobin concentrations below $6.0 \mathrm{~g} / \mathrm{dl}$.

Severity of anaemia before, during, and after hepatic cytolysis. Values are means $\pm S D$

\begin{tabular}{|c|c|c|c|c|c|c|c|}
\hline & & & & & Before & During & After \\
\hline Mean cell volume $(\mathrm{fl})$ & $\ldots$ & . & . & $\ldots$ & $83 \cdot 3 \pm 7 \cdot 3$ & $87 \cdot 8 \pm 7 \cdot 6^{*}$ & \multirow{4}{*}{ 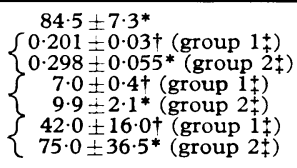 } \\
\hline Packed cell volume & .. & .. & .. & . & $0.204 \pm 0.037$ & $0 \cdot 280 \pm 0.053 \dagger$ & \\
\hline \multicolumn{3}{|c|}{ Haemoglobin concentration $(\mathrm{g} / \mathrm{dl})$} & . & .. & $6 \cdot 8 \pm 1 \cdot 4$ & $8.9 \pm 1.8 \dagger$ & \\
\hline \multicolumn{3}{|c|}{ Reticulocyte count $\left(\times 10^{9} / 1\right)$} & . & . & $48 \cdot 7 \pm 20 \cdot 9$ & $85 \cdot 8 \pm 36 \cdot 6 \dagger$ & \\
\hline
\end{tabular}

be more important than other factors, however, since the anaemia is more severe in anephric subjects than in other uraemic patients receiving haemodialysis. ${ }^{4}$

During an episode of liver cytolysis in patients receiving haemodialysis we observed an increase in circulating reticulocytes and, in many cases (including two anephric patients), a significant reduction in the anaemia. We therefore investigated

Centre Hospitalier, F-22000 Saint-Brieuc, France

PIERRE SIMON, MD, chief of nephrology and haemodialysis unit TUGDUAL TANQUEREL, MD, medical assistan

Hôpital Tenon, F-75970 Paris 20, France

ALAIN MEYRIER, MD, consultant nephrologist and chief of haemodialysis unit

KIM-SENG ANG, MD, fellow in nephrology

\section{Results}

The 30 patients fell into two distinct groups-namely, 19 patients (group 1) in whom the duration of liver cytolysis (mean $5 \cdot 0 \pm \mathrm{SD}$ 2.9 months) was compatible with "acute" hepatitis, and 11 patients (group 2) in whom the duration (mean $8.0 \pm 3.5$ months) was compatible with "chronic" hepatitis. ${ }^{5}$ This difference was significant $(\mathrm{p}<0.02)$.

When all patients were considered the episode of liver cytolysis was accompanied by significant increases $(p<0.001)$ in mean packed cell volume, haemoglobin concentration, and reticulocyte count (table). The mean cell volume, however, was unchanged. Figure 1 shows the changes in haemoglobin concentrations and circulating reticulocytes in groups 1 and 2 considered separately. With the reduction in anaemia the four patients who had been intolerant of haemoglobin concentrations below $6.0 \mathrm{~g} / \mathrm{dl}$ no longer required blood transfusions (fig 2). Of these, three had been receiving 1-3 units of packed cells monthly, and one (case 1) - the patient with chronic respiratory failure-had needed 4 units monthly. In the remaining 
26 patients the amelioration of anaemia began $11.0 \pm S D 5.0$ weeks after the initial rise in serum ALT activity. All patients were greatly improved in their general condition, wellbeing, and tolerance of exertion during the episode.

In group 1 the improvement in anaemia lasted for a mean of $12 \cdot 0$ SD 6.0 weeks. The mean reticulocyte count then decreased $(\mathrm{p}<0.001)$ and the haemoglobin concentration and packed cell volume returned to precytolysis values (fig 1). Of the 11 patients in group 2 , seven continued to have an improved reticulocyte count, haemoglobin concentration, and packed cell volume a mean of 30.0 16.0 weeks after cytolysis, though in the other four these values had diminished. Needle biopsies in eight patients in this group showed chronic persistent hepatitis in five, chronic active hepatitis in two, and cirrhosis in one.

The two anephric patients were in group 2. In one (case 4 ; fig 2 ) cytolysis and then cholestasis were still present 78 weeks after beginning and 52 weeks after stopping treatment with paracetamol

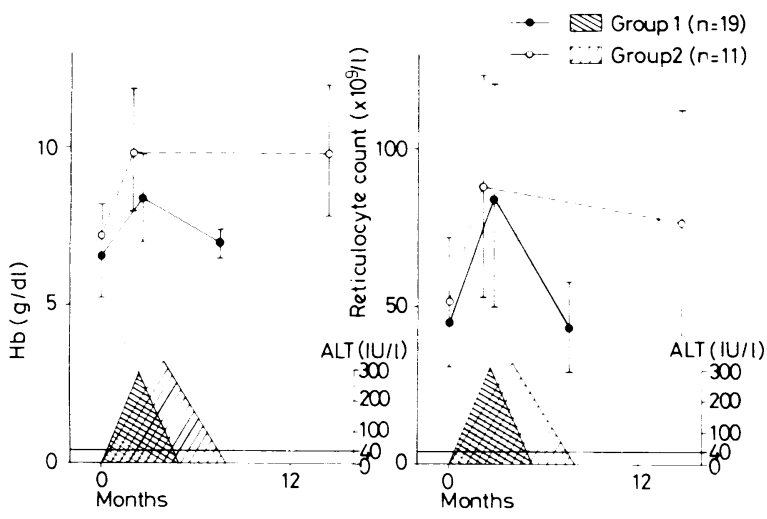

FIG $1-$ Mean ( \pm SD) haemoglobin concentrations and reticulocyte counts in groups 1 and 2 before, during, and after episode of liver cytolysis. and aspirin. The improvement in anaemia was also maintained. In the other patient cytolysis due to HBsAg hepatitis lasted for 35 weeks. During this period the anaemia was improved. Fifteen weeks after the disappearance of cytolysis she became HBsAg-negative, and subsequently her packed cell volume fell to precytolysis values.

\section{Discussion}

The anaemia of chronic renal failure results from the inability of erythropoiesis to compete with blood losses and accelerated red-cell destruction. ${ }^{1}$ Probably many factors contribute to the impaired production of red cells, including uraemic toxicity ${ }^{2}$ and inadequate secretion of erythropoietin. ${ }^{3}$ That lack of renal erythropoietin may be a dominant factor, however, was strongly suggested by evidence that the anaemia is more severe in anephric subjects than in other patients receiving haemodialysis.

In our series of uraemic patients an episode of viral or toxic liver damage was accompanied by improved erythropoiesis. The possibility that this resulted from a diminution of hepatic inhibitors of residual renal erythropoietin, however, is ruled out because the two anephric patients also showed improvement, with increased reticulocyte counts and a sustained reduction in their anaemia. Kolk-Vegter et $a l^{6}$ and Coleman et $a l^{7}$ reported similar observations in 11 anephric patients.

We postulate that in our patients the injured liver became a source of extrarenal erythropoietin. The delayed onset of reticulocytosis after the beginning of cytolysis suggests that hepatocyte regeneration rather that hepatocyte destruction was the stage when this erythropoietin secretion occurred. Possibly regenerating hepatocytes recover some of their function observed in the fetus. ${ }^{8}$

That the liver may produce erythropoietin is supported clinically and experimentally. Fried ${ }^{9}$ and Naughton et $a l^{10}$ found that regenerating hepatocytes played an important part
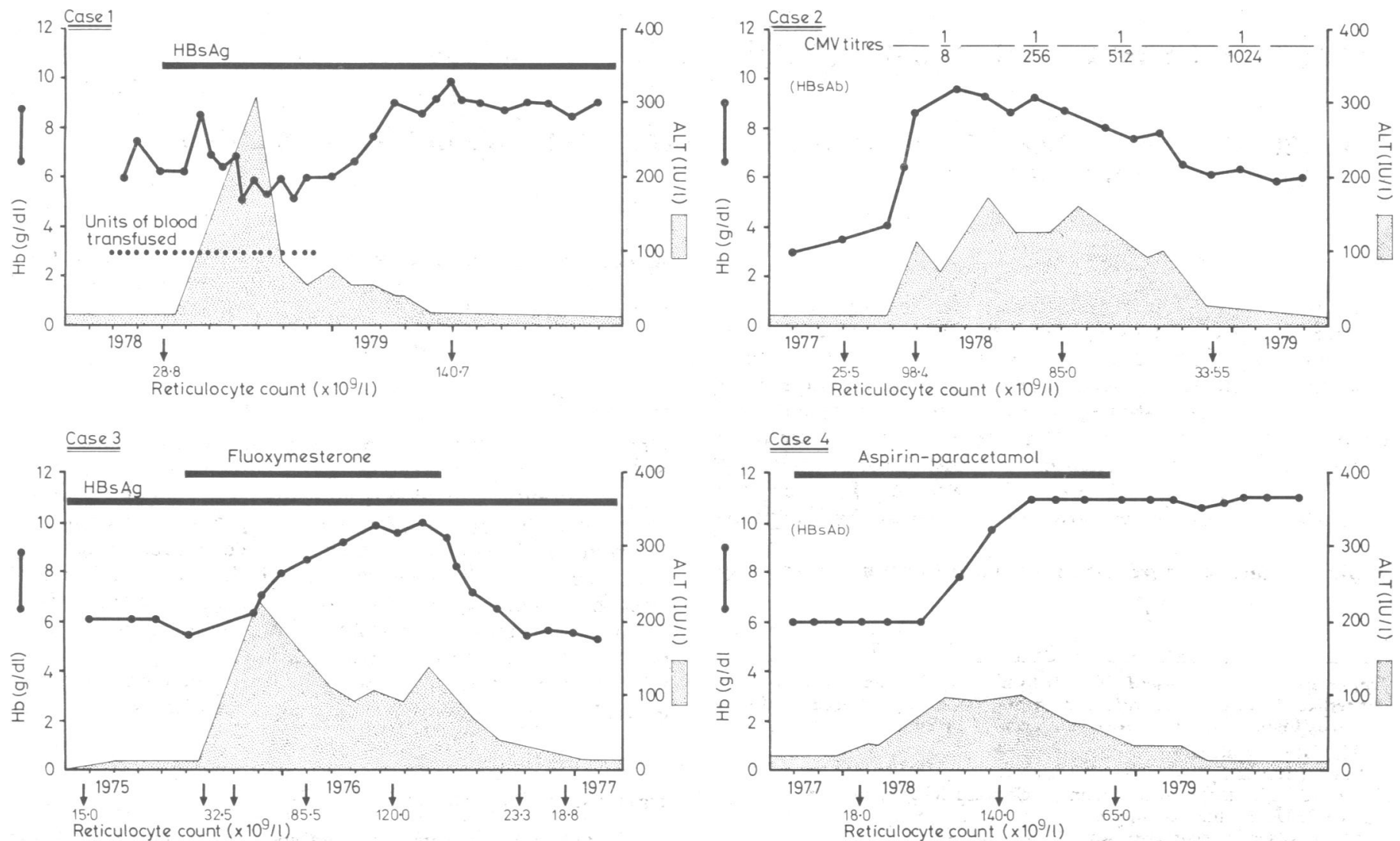

FIG 2-Results of liver cytolysis in four patients who before onset had needed regular blood transfusions for their anaemia. Case 1 (group 2): 66 -year-old man with HBsAg hepatitis. Case 2 (group 1): 17-year-old youth with CMV hepatitis (HBsAb-positive). Case 3 (group 1): 60-year-old woman (carrier of HBsAg) with toxic liver cytolysis. Case 4 (group 2): 40-year-old anephric woman (HBsAb-positive) with toxic liver cytolysis. 
in the production of extrarenal erythropoietin in rats, and Cannon and Pennington ${ }^{11}$ and Gordon et al ${ }^{12}$ reported erythropoietin secretion by primary liver tumours in man. Possibly the erythrocytosis of acute viral hepatitis ${ }^{13}$ is also mediated by erythropoietin, though that remains to be investigated.

Other workers have noted increased haemoglobin concentrations in uraemic patients with HBsAg hepatitis. ${ }^{6}$ 7 Our findings show that drug-induced liver cytolysis also increases red-cell production in uraemia. We have documented elsewhere the unsuspected number of hepatotoxic drugs that are prescribed in uraemia, ${ }^{14}$ which may explain the reportedly beneficial effects of androgens $s^{15}{ }^{16}$ and intravenous iron $^{17}$ on the anaemia of chronic renal failure.

Interestingly our patients in group 2 showed an apparent correlation between persistently raised haemoglobin concentrations and biopsy evidence of chronic hepatitis. ${ }^{14}$ If this is confirmed a sustained improvement in anaemia after liver cytolysis could be used as additional evidence in tests for persisting liver damage.

Finally, possibly some forms of liver extracts could be utilised for treating renal anaemia.

Requests for reprints should be sent to Dr Alain Meyrier.

\section{References}

1 Naets JP. Anémie rénale. In: Kuss R, Legrain M, eds. Séminaires d'UroNéphrologie. Vol 5. Paris: Masson, 1979:121-36.

${ }^{2}$ Erslev AJ. The effect of uremic toxins on the production and metabolism of erythropoietin. Kidney Int 1975; suppl 2:8-12.

${ }^{3}$ Fisher JW, Barona J, Martinez M, Rege AB. Role of erythropoietin and inhibitors of erythropoiesis in the anemia of renal insufficiency. Dialysis and Transplantation 1978;7:472-81.
${ }^{4}$ Naets JP, Wittek M, Toussaint C, Van Geertruyden J. Erythropoiesis in anephric man. Ann NY Acad Sci 1968;149:143-5.

${ }^{5}$ Sherlock S. Diseases of the liver and biliary system. 4th ed. Oxford: Blackwell, 1969.

${ }^{6}$ Kolk-Vegter AJ, Bosch E, Van Leeuwen AM. Influence of serum hepatitis on haemoglobin level in patients on regular haemodialysis. Lancet 1971 ; i:526-8.

7 Coleman JC, Eastwood JB, Curtis JR, Fox RA, Edwards M. Hepatitis and epidemic hepatitis-associated antigen (EHAA) in a haemodialysis unit with observations on haemoglobin levels. $B r f$ Urol 1972;44: 194-201.

${ }^{8}$ Lucarelli G, Porcellini A, Carnevali C, Carmena A, Stohlman F Jr. Fetal and neonatal erythropoiesis. Ann NY Acad Sci 1968;149:544-7.

${ }^{9}$ Fried W. The liver as a source of extrarenal erythropoietin production. Blood 1972;40:671-7.

10 Naughton BA, Kaplan SM, Roy M, Burdowski AJ, Gordon AS, Piliero J. Hepatic regeneration and erythropoietin production in the rat. Science 1977;196:301-2.

${ }^{11}$ Cannon P, Pennington DG. Erythropoietin and hepatoma. Lancet 1967; ii:1276-7.

${ }^{12}$ Gordon AS, Esmail D, Zanjani ED, Zalusky R. A possible mechanism for the erythrocytosis associated with hepatocellular carcinoma in man. Blood 1970;35:151-3.

${ }^{13}$ Bank H, Passwell J. Absolute erythrocytosis in early infectious hepatitis. Med Chir Dig 1974;3:321-3.

${ }^{14}$ Simon P, Herry D, Brissot P, Cougard A, Meyrier A. Long-term follow-up of chronic hepatitis by serial liver biopsies in HBs-positive haemodialysis patients; role of hepatotoxic drugs. In: Robinson HB, Hawkins JB, eds. Proceedings of the European Dialysis and Transplant Association. Vol 15. Istanbul: Pitman, 1978;596-9.

${ }^{15}$ Shaldon S, Kock KM, Oppermann F, Patyma WD, Schoeppe W. Testosterone therapy for anaemia in maintenance dialysis. $\mathrm{Br}$ Med $\mathcal{f}$ 1971; iii :212-5.

${ }^{16}$ Fried W, Jonasson O, Lang G, Schwartz F. The hematologic effect of androgen in uremic patients. Study of packed cell volume and erythropoietin responses. Ann Intern Med 1973;79:823-8.

17 Stewart WK, Fleming LW, Shepherd AMM. Haemoglobin and serum iron responses to periodic intravenous iron-dextran infusions during maintenance haemodialysis. Nephron 1976;17:121-9.

(Accepted 15 fanuary 1980)

\title{
Sleep apnoea in acromegaly
}

\author{
W H PERKS, P M HORROCKS, R A COOPER, S BRADBURY, A ALLEN, N BALDOCK, \\ K PROWSE, W VAN'T HOFF
}

\section{Summary and conclusions}

Daytime somnolence or excessive snoring, or both, occurred in five out of 11 patients with acromegaly. All five had episodes of sleep apnoea, and three had the sleep apnoea syndrome. Growth hormone concentrations were higher $(p<0.025)$ in these patients than in the six patients without these symptoms. One patient with daytime somnolence and one asymptomatic patient had flow loop evidence of upper airways obstruction. Two of the patients with the sleep apnoea syndrome had cardiomegaly.

Sleep apnoea appears to be common and clinically

\footnotetext{
Departments of Clinical Neurophysiology, Endocrinology, Biomedical Engineering, and Respiratory Physiology, North Staffordshire Hospital Centre, Stoke on Trent, Staffordshire

W H PERKS, MB, MRCP, senior registrar

P M HORROCKS, MB, MRCP, registrar

R A COOPER, MB, FRCP, consultant in clinical neurophysiology

$S$ BRADBURY, chief technician

A ALLEN, senior technician

N BALDOCK, MB, MRCP, registrar

K PROWSE, MD, FRCP, consultant physician

W VAN'T HOFF, MB, FRCP, consultant physician
}

important in acromegaly, and it may be central, obstructive, or mixed. Polygraphic nocturnal monitoring is indicated to assess these patients properly.

\section{Introduction}

Upper airways obstruction may be a complication of acromegaly owing to enlargement of the soft tissues of the oropharynx. ${ }^{1}$ Upper airways obstruction from many causes may be associated with daytime somnolence and repeated episodes of sleep apnoea. ${ }^{2}$ Sleep apnoea ${ }^{3}{ }^{4}$ and daytime somnolence ${ }^{5}$ in acromegaly have been reported. The daytime somnolence may remit rapidly after the acromegaly has been treated, ${ }^{5}$ suggesting that it is not solely due to anatomical abnormalities of upper airways. We have studied 11 patients with acromegaly to determine the relation between upper airways obstruction, daytime somnolence, and sleep apnoea and the prevalence of these features.

\section{Patients and methods}

We studied 11 patients (five men and six women); table I gives clinical details. Acromegaly had been confirmed in all cases by the finding of raised growth hormone concentrations that did not fall after a glucose load. Two patients (cases 8 and 9 ) were newly diagnosed 